\title{
Understanding Patterns of College Outcomes among Student Veterans
}

\author{
Nathan Durdella (Corresponding author) \\ Educational Leadership and Policy Studies, California State University, Northridge \\ 18111 Nordhoff Street, Northridge, California 92831, United States \\ Tel: 1-818-677-3316_E-mail: nathan.durdella@csun.edu \\ Young K. Kim \\ Doctoral Higher Education, Azusa Pacific University \\ 701 East Foothill Boulevard, Azusa, California 91702-7000, United States \\ Tel: 1-626-815-5053Ｅ-mail: ykkim@apu.edu
}

Received: March 2, 2011

$10.5296 /$ jse.v2i2.1469
Accepted: March 26, 2012 Published: May 1, 2012

URL: http://dx.doi.org/10.5296/jse.v2i2.1469

\begin{abstract}
Even as we expect an increase in veteran student enrollment in higher education, little attention has been paid to the role students' background characteristics and college experiences play in college outcomes among student veterans. The purpose of this study is to examine differences in precollege characteristics and college experiences between veteran and nonveteran students and a predictive power of being a veteran student on college outcomes. Using data from the 2008 University of California Undergraduate Experience Survey (UCUES), the study conducted cross tabulations and blocked multiple regression analyses on two college outcomes: college GPA and sense of belonging. Results demonstrate that student veteran status is negatively associated with college GPA. The origins of the negative effect of being a veteran student are discussed.
\end{abstract}

Keywords: Students, Veterans, College outcomes 


\section{Introduction}

Although previous research has well documented the relationship of student input characteristics and college experiences to student success in college using aggregate college student samples (e.g., Astin, 1993; Pascarella \& Terenzini, 2005), little attention has been paid to such relationship among veterans in college. In fact, we know much less about what student veterans input characteristics are and how they experience college as compared to their college peers who are not veterans. Further, we do not know exactly how being a veteran affects student outcomes, particularly college GPA and sense of belonging in college. Given that first-year college GPA predicts retention, persistence, and achievement (Allen et. al. 2007; Wang, 2009; Pascarella and Terenzini, 2005) and sense of belonging is a key outcome of college students' experiences and intention to persist (Bollen \& Holye, 1990; Hausmann, et. al., 2007), the need to understand how student veteran characteristics and experiences affect them is important.

Understanding who student veterans are and how being a veteran in college affects their GPA and sense of belonging is even more pressing when we consider that the undergraduate student veteran population in U.S. colleges and universities stood at $3.1 \%$ of all undergraduates (Radford \& Wun, 2009), we expect an increase in student veteran enrollment as some of the nearly two million veterans from Iraq and Afghanistan return home and use expanded educational benefits from a post-9/11 GI Bill (Steele et. al., 2010; Radford, 2009). As more veterans enroll in college, the need to understand how they experience college and how their status as veterans affects their college experiences and outcomes seems to be more promising.

The purpose of this study is to examine differences in precollege characteristics and college experiences between student veterans and their nonveteran student counterparts and investigate the unique predictive power of being a student veteran on college outcomes. The latter examination focuses on whether being a veteran college student significantly affects two traditional college outcomes - college GPA and sense of belonging in college-after controlling for an extensive set of confounding variables including student input characteristics, college environments, and college experiences. Specifically, this study seeks to answer the following research questions: (1) Do student veterans have different patterns in their background characteristics, choice of major field, and college experiences compared to nonveteran students? (2) Does veteran status predict college GPA and sense of belonging after controlling for the effects of other student characteristics, major field, and college experiences? (3) If so, what are the conditions and characteristics that contribute to this pattern?

\section{Background and Literature Review}

\section{I Precollege Characteristics and Experiences of Veterans}

Military service tends to be associated with an array of physical, emotional, and educational outcomes that vary by pre-service background characteristics and service-related experiences. In fact, the "signature" injuries of Operation Iraqi Freedom (OIF) veterans is post-traumatic 
stress disorder (PTSD) and traumatic brain injury or TBI (Burke, Degeneffe, \& Olney, 2009), which often leads to visual and hearing impairment (Lew et. al., 2009). In addition, mental and physical health condition related chronic fatigue syndrome (Dhillon \& Boyd, 2010) and, more frequently for female veterans, military sexual trauma (Campbell \& Raja, 2005) can accompany military service.

As a group, veterans tend to achieve lower levels of degree attainment than their nonveteran counterparts (Teachman, 2005). In fact, Teachman found that short- and long-term educational gaps between veterans and nonveterans exist. Whether this is related to their military service or their input characteristics before military service remains less certain. What we do know about military service is that depending on service-related characteristics time spent in the military delays or disrupts the life course. Teachman (2004) found that draft status had a negative effect on future earnings although the effect diminishes over time, while draft status, schooling prior to college, and age at entry into the military all had overall negative effects on educational attainment after the military (2005). One reason that may explain lower levels of degree attainment among veterans relates to a military institutional culture that seems to socialize enlisted personnel away from higher education (McNealy, 2004).

During the college choice process, veterans tend select institutions based on financial considerations rather than institutional reputation, selectivity, or proximity. In fact, McNealy (2004) found that veterans select two-year over four-year universities for perceived financial benefits. In addition, McNealy described a rationale for this decision related to an ability to back financial resources saved while at a community college. However, Steel et. al. (2010) found that veteran college choice is more nuanced than previously thought and varies by veteran subgroup. In fact, veterans at public four-year and private non-profit institutions reported that degree programs and institutional reputation were major factors in decisions to enroll, while veterans at public two-year and private for-profit institutions tended to enroll for reasons related to proximity, familiarity, and an institutional focus on adult, nontraditional learners. (Steele et. al.)

During the college choice process, GI educational benefits in particular and financial aid in general tend to influence veterans' decisions. With respect to financial aid, veterans tend to boost their total aid levels above nonveterans' aid levels with GI educational benefits (U.S. General Accounting Office, 2002). When students receive aid packages that include Pell grants and Stafford loans, veterans generally carry a lower proportion of loans than nonveterans (U.S. General Accounting Office). In fact, the availability of educational benefits - along with emotional support from family - tends to influence veterans' decisions to enroll in college (Ly-Turnbull, 2010). When aid levels increase - as they did with the Post-9/11 GI Bill - veterans report that these resources influence the college choice process both in terms of decisions about to enroll and where to apply (Steele et. al., 2010). The use of educational benefits tends to increase the number of years of degree completion among veterans (Angrist, 1993). 


\subsection{Veteran Student Experiences and Outcomes in College}

Once the college choice process ends, veterans' college experiences and outcomes tend to vary by their precollege characteristics including demographics, pre-service experiences, and service-related experiences. In fact, Ly-Turnbull (2010) found that veterans tend to retain their values from the military as they make a transition to college, which could help explain why veterans tend to perceive colleges and universities as more chaotic, less ordered, and less authoritative institutions than military ones (Rumann, 2010). Given the tendency to retain value orientations and experiences from the military, veterans report a period of role negotiation and identify formation during the transition from the military to college (Rumann and Hamrick, 2010). Indeed, veterans tend to work to reconcile military with academic cultures and report the need to successfully do so in order to renegotiate their identities (Rumann and Hamrick). Perhaps related to these dynamics - and the challenges that veterans report with balancing academic work with family and work responsibilities (Steele et. al. 2010) — veterans tend to leave college for reasons related to stress.

Not surprisingly, veterans tend to experience college differently than nonveterans. Specifically, veterans service-related experiences, particularly extended deployments overseas, tends to complicate the transition to college, although factors like timing of transition and length of deployment seem to affect transition issues (Rumann, 2010). Cognitively, veterans tend to exhibit difficulty relearning critical thinking skills and expectations of academic work (Rumann, 2010; Steele et. al. 2010); however, this finding seems to conflict with the finding that veterans generally are academically focused (Livingston, 2009). Outside the classroom, student veterans tend to socialize less with nonveterans and engage less with campus life (Livingston).

\subsection{College GPA and Sense of Belonging in College}

We have a good sense of how precollege student characteristics and college student experiences affect GPA and sense of belonging. With respect to students' background characteristics, the personality traits associated with academic self-efficacy (Zajacova et al., 2005) and conscientiousness (Richardson \& Abraham, 2009; Noftle \& Robins, 2007; Nguyen et. al., 2005) positively predict college GPA. In fact, the relationship between conscientiousness and GPA seems to be mediated by higher levels of achievement motivation (Richardson \& Abraham), increased academic effort, and higher levels of academic ability (Noftle \& Robins). In terms of the effects of college experiences on GPA, study habits and test-taking strategies predict college GPA (Hall et. al., 2008). In particular, efficient use of time (Kelly, 2004) and time management skills (Kern et. al., 1998) relate to higher college GPA. Further, there seems to be a positive relationship between academic participation and hours spent on campus and GPA (Grayson, 1997). Kim and Sax (2009) found that course- and research-related student-faculty interaction positively predicted college GPA, although the effects varied by student racial subgroups.

The feeling of belonging on campus is related to persistence among first-year students (Hoffman, Richmond, Morrow, and Salomone, 2002) and an overall quality of life among all students (Jones, 2003). When we turn to the effects of student characteristics and college 
experiences, we know that both academic and social factors relate to a sense of belonging in college. In fact, the relationship between student feelings of academic integration and sense of belonging tend to be positive (Hausman et. al. 2007). Further, when students feel that their studies apply to their everyday lives, they tend to have a higher level of sense of belonging (Hurtado el. al., 2007). When students participate in a cohort program, we see a positive effect on sense of belonging in the program and the larger campus community, particularly among students of color (Lucas \& Robinson, 2003). Beyond campus, students' family connections seem to play a prominent role in their sense of belonging on campus, except when these connections interfere with college (Hurtado et. al.). In particular, non-science students of color and White and Asian science students' strong family connections positively relate to their sense of belonging as first-year students. However, family connections benefit students' sense of belonging to an extent, as the more parental support a first-year student has the faster the decline in sense of belonging over time (Hausman et. al.). In the case of Asian American students, strong cultural connections tend to support a sense of belonging on campus (Lee \& Davis, 2000).

\section{Research Framework}

We used two models to understand how the experiences of college student veterans differ from their counterparts who are not veterans and how their status as veterans affects both college GPA and sense of belonging in college: college student involvement theory and cultural models of student learning. Given that student veterans enter college with different background characteristics and that we are interested in two traditional student outcomes - college GPA and sense of belonging in college-we turned to a student involvement theory to analyze and interpret differences in experiences and outcomes. Specifically, we used Astin's involvement theory (1984) to explain student veteran experiences and outcomes. Astin argues that students develop more when they investment more time and energy in their college experiences.

While Astin's model explains a basic underlying relationship between college student involvement and outcomes, we argue that in the case of student veterans a more meaningful explanation includes a recognition that students' backgrounds - their cultural backgrounds, in particular - act as an intervening factor in their involvement, investment, and experiences in college. Indeed, we know that veterans maintain their military identities and military cultural values throughout college, so we used a culturally-based explanation of student experiences to explain patterns college experiences and outcomes. Cultural models of student learning argue that students interpret their learning experiences through the lens of their membership in cultural groups (Moody, 2004; Banks, 1993). When student experiences are incongruent with cultural knowledge, behavior, and values, then students experience conflict that can affect their learning. By including these cultural models as well as using student involvement theory, this study attempts to expand the traditional view on college students' college experiences and outcomes.

\section{Methods}

\subsection{Data Source and Sample}

The study used data from the 2008 University of California Undergraduate Experience 
Survey (UCUES) core items and academic engagement and student development modules, which were matched to student records data from the University of California (UC) system's office. The UCUES is a biennial online survey of all UC undergraduate students administered by the UC Berkeley Office of Student Research and managed by the UC Office of the President. The core items sample all undergraduates at nine UC campuses (Berkeley, Davis, Irvine, Los Angeles, Riverside, San Diego, Santa Barbara, Santa Cruz, and Merced) to collect information on student background characteristics, academic and personal development, academic engagement, satisfaction, and evaluation of major. Each of the academic engagement and student development modules targets a randomly selected $20 \%$ of students at each UC campus to collect information on students' college experiences and their educational growth and development, respectively. The systemwide response rate for the 2008 UCUES was $39.2 \%$, reporting 63,528 respondents out of 162,061 eligible participants. Generally speaking, the UCUES respondent sample is a good reflection of the UC undergraduate population (Chatman, 2007a).

The analytical sample for this study was limited to those students who completed all of the three modules of our interest - i.e., core, academic engagement, and student development modules, and it consisted of 21,179 students. Overall, the sample was traditional age (83.4\% 18 to 22 ), female (56.8\%), and ethnically diverse (37.5\% Asian, 34.5\% White, 15.4\% Latino, and $3.0 \%$ African American). With respect to veteran status, less than $1 \%(0.8 \%)$ of respondents in the sample reported being a veteran $(n=163)$. The veteran sample was nontraditional age (84.7\% 23 and older), male (73.0\%), and predominantly white $(45.4 \%$ White, 22.1\% Asian, 14.7\% Latino, 3.7\% African American).

\subsection{Variables}

Outcome variables. Given that student veteran population in the U.S. higher education has been historically understudied in college impact literature and this study attempts to fill the research gap by improving our general understanding of the population, we selected two traditional college outcome measures, one from a cognitive (i.e., GPA) and another from an affective developmental area (i.e., sense of belonging). Students' college GPAs were assessed by their actual GPAs reported by the UC system record, while students' sense of belonging were gauged by a factor scale that consisted of six items in the UCUES 2008 core module. The six items in the factor scale included ratings of levels of satisfaction with UC GPA, overall social experience, overall academic experience, value of education for the price and ratings of levels of agreement with "I feel that I belong at this campus" and "Knowing what I know now, I would still choose to enroll at this campus" $(\alpha=.82)$.

Independent variables. The analytical design for this study was guided by Astin's Input-Environment-Outcome (I-E-O) framework (1993), which suggests organizing independent variables in temporal order based upon when they might affect the dependent variables (Kim \& Sax, 2009; Sax, 1994). Although Astin's I-E-O model is mainly interested in accounting for college student population's educational behavior, the underlying principles of his model is also applicable to veteran population, telling us that veterans' background characteristics and their college environments and experiences affect their outcomes (i.e., 
college GPA and sense of belonging in this case). Using this framework and drawn from the UCUES 2008 core items as well as its academic engagement and student development modules and the UC system's student records, independent variables of the present study were grouped into the following three blocks: 1) student input characteristics (i.e., gender, race, age, parent's income, freshman status, student level, and veteran status), 2) academic major fields, and 3) college experiences (i.e., academic participation and interaction, collaborative work, campus climate for diversity, extracurricular engagement, time employed, and academic time). Refer to Appendix A to see a list of variables that were used for this study and their coding schemes. Means and standard deviations for all continuous variables used in this study are also presented in Table 1 for separate samples of nonveteran and veteran students.

Table 1. Mean and Standard Deviations of Outcome, Demographic, and College Experience Variables by Nonveteran and Veteran Students

\begin{tabular}{lll}
\hline Variables & $\begin{array}{l}\text { Nonveteran } \\
(\mathrm{n}=19,845)\end{array}$ & $\begin{array}{l}\text { Veteran } \\
(\mathrm{n}=153)\end{array}$ \\
\hline College GPA & $3.11(.57)$ & $3.03(.56)$ \\
Sense of Belonging & $5.04(1.90)$ & $4.96(2.17)$ \\
Age & $19.21(3.32)$ & $26.98(6.85)$ \\
Academic Participation and Interaction & $4.72(1.84)$ & $5.59(2.03)$ \\
Collaborative Work & $4.90(1.95)$ & $4.96(2.30)$ \\
Campus Climate for Diversity & $5.30(1.81)$ & $5.20(2.01)$ \\
Extracurricular Engagement & $4.90(1.76)$ & $4.14(1.71)$ \\
Time Employed & $4.29(1.58)$ & $4.54(1.61)$ \\
Academic Time & $5.09(1.91)$ & $5.38(1.99)$ \\
\hline
\end{tabular}

\subsection{Analysis}

First, we performed a descriptive analysis to examine a central tendency and a distribution of students on all continuous variables used in the study. Then, we performed blocked multiple regression analyses for each of the college outcome measures-i.e., college GPA and sense of belonging, using the full sample, to examine whether being a veteran student has a significant effect on the outcomes after taking the confounding effects of student inputs, academic majors, and college experiences into account. While the college student data tend to have a 
hierarchical structure, where students are nested in institutions, this study employed the ordinary least squares (OLS) method instead of using multilevel modeling because we were more interested in investigating unbiased unique effects of veteran status on college outcomes rather than examining any cross-level effects of it. Indeed, given that the UCUES data were collected from nine undergraduate campuses in a research university system, they share numerous structural and organizational similarities (Chatman, 2007b) and tend to have little between-institution variances. Lastly, cross-tabulation analyses were conducted to see if there exist different patterns in a selected set of precollege characteristics and college experiences between student veterans and nonveteran counterparts. Chi-square statistics were also computed to detect whether the differences observed from the cross-tabulations were statistically significant.

\section{Results}

\subsection{Veteran Effect on College Outcomes}

What are the patterns of college student outcomes for veteran college students? Do veteran students tend to have a lower level of college outcomes than their civilian peers? The descriptive statistics in Table 1 answer to this first research question of the study. The results seem to show that veteran students tend to have both lower college GPAs and lower level of sense of belonging than their civilian peers. Veteran students reported their average college GPA of 3.03, while nonveteran students reported the average GPA of 3.11. Similarly, veteran students on average had a lower level of sense of belonging $(\mathrm{m}=4.96)$ compared to their nonveteran counterparts $(\mathrm{m}=5.04)$.

Although we have a sense of patterns in veteran students' college outcomes from these descriptive results, we conducted additional analyses to provide a more rigorous answer to the first research question. For the analyses, we conducted blocked multiple regression analyses where we used being a veteran student as our main independent variable, two outcome measures (i.e., college GPA and sense of belonging) as dependent variables, and a selected set of student demographic characteristics, input characteristics, major field of study, and college experiences as control variables. Through the regression analyses, we could examine the net veteran effect - unbiased and unique effect of being a veteran student on their college outcomes (i.e., college GPA and sense of belonging in this case)-controlling for an intensive set of confounding variables. 


\section{Macrothink}

Table 2. Standardized Regression Coefficients for Variables That Predict College GPA and Sense of Belonging among College Students

\begin{tabular}{|c|c|c|}
\hline Variable & GPA & Sense of Belonging \\
\hline \multicolumn{3}{|l|}{ Student Input Characteristics } \\
\hline Female & $.01 * * *$ & $-.01 * * *$ \\
\hline African American & $-.09 * * *$ & $-.02 * * *$ \\
\hline Latino & $-.18 * * *$ & $-.02 * * *$ \\
\hline Asian American & $-.08 * * *$ & $-.15 * * *$ \\
\hline Age & $.03 * * *$ & $.06 * * *$ \\
\hline Parent's Income & $.13 * * *$ & $.06 * * *$ \\
\hline Freshman Status & $.33 * * *$ & $.11 * * *$ \\
\hline Student Level & $.34 * * *$ & $.05 * * *$ \\
\hline Veteran Status & $-.02 * * *$ & $-.01 * * *$ \\
\hline \multicolumn{3}{|l|}{ Major Fields } \\
\hline Major Engineering or Applied Science & $-.11 * * *$ & $-.01 * * *$ \\
\hline Major Science or Math & $-.14 * * *$ & $-.04 * * *$ \\
\hline Major Social Science & $-.04 * * *$ & $.01 * * *$ \\
\hline Major Arts and Communications & $.02 * * *$ & $.02 * * *$ \\
\hline Major Business & $-.04 * * *$ & $-.01 * * *$ \\
\hline Major Humanities & $.03 * * *$ & $.03 * * *$ \\
\hline \multicolumn{3}{|l|}{ College Experiences } \\
\hline Academic Participation and Interaction & $.09 * * *$ & $.11 * * *$ \\
\hline Collaborative Work & $.02 * * *$ & $.14 * * *$ \\
\hline Campus Climate for Diversity & $-.01 * * *$ & $.33 * * *$ \\
\hline Extracurricular Engagement & $-.13 * * *$ & $.07 * * *$ \\
\hline Time Employed & $-.05 * * *$ & $-.03 * * *$ \\
\hline \multirow[t]{2}{*}{ Academic Time } & $.10 * * *$ & $.01 * * *$ \\
\hline & $\mathrm{R}^{2}=.16$ & $\mathrm{R}^{2}=.23$ \\
\hline
\end{tabular}

$* \mathrm{p}<.05, * * \mathrm{p}<.01, * * * \mathrm{p}<.001$.

Table 2 displays the final standardized regression coefficients of student input characteristics, major fields, and college experiences on college GPA and sense of belonging. Results indicate that being a veteran student has a unique negative predictive power on college GPA 
but not on sense of belonging after controlling for the effects of other independent variables. That is, being a veteran student was significantly and negatively associated with college GPA $(\beta=-.02, p<.01)$ while it had no significant relationship with sense of belonging $(\beta=-.01$, $\mathrm{p}>.05)$. The results suggest that veteran students tend to have relatively lower college GPAs than nonveteran students even after taking the confounding effects of other independent variables into account. Although being a veteran student was our item of interest in the regression analyses, results from the regressions also identified some key predictors for college students' college GPA and sense of belonging, and they gave us an insight to answer our second research question. We will discuss the predictors later in this study.

\subsection{Characteristics and Conditions that Contribute to Veteran Effect}

Given that the descriptive statistics presented earlier in this study established that veteran college students tend to have lower college GPA and lower level of sense of belonging compared to nonveteran students, our inquiry naturally moved to factors that contribute to such patterns. Also, regression results in Table 2 show that the net effect of being a veteran student on the outcomes of this study is either significant but trivial or statistically non-significant once we control for student input, college environment, and experience variables. These findings all together suggest that most of veteran effect (i.e., negative effect of being a veteran student on college outcomes) seem to be explained by the traits they bring when they enter the college and their experiences during college years. Consequently, to identify some key characteristics and experiences that help to understand a veteran effect, we considered those key student characteristics and experiences that significantly predicted college GPA and/or sense of belonging in our regression analyses. Then, we cross-tabulated those variables across veteran and nonveteran students to assess whether there are unique patterns for veteran students concerning the variables.

\subsubsection{Student Input Characteristics.}

Beginning with some input characteristics that were found earlier in the regression analyses to improve college GPA and/or sense of belonging, the cross-tabulations results show that student veterans were less likely to have those characteristics. Our regression results earlier showed that family annual income has a positive effect on both college GPA $(\beta=.13, p$ $<.001)$ and sense of belonging $(\beta=.06, \mathrm{p}<.001)$. When we cross-tabulated family annual income by students' veteran status, results suggest that veteran students tend to have relatively lower level of family incomes than their civilian peers. That is, only $21.1 \%$ of student veterans fell into the high annual income range (that is, upper quartile range), whereas $35.2 \%$ of nonveteran students fell into such category (see Table 3 ). Similarly, being a freshman also has a positive effect on both college GPA $(\beta=.33, p<.001)$ and sense of belonging $(\beta=.11, \mathrm{p}<.001)$ in the regression analyses, and our cross-tabulation results showed that there is a big difference in student distributions on the variable between veteran and nonveteran students. Results indicated that only $8.0 \%$ of veteran students were freshmen whereas $72.5 \%$ of non-veteran students were so. 


\section{Macrothink}

Table 3. Student Input Characteristics as a Percentage of Nonveteran and Veteran Student Sample

\begin{tabular}{llll}
\hline Input Characteristics & Nonveteran & Veteran & Chi-Square \\
\hline Parent's income $(\mathrm{n}=19,777)$ & & 29.6 & $12.27^{*}$ \\
Low Level & 24.4 & 49.3 & \\
Medium Level & 40.4 & 21.1 & \\
High Level & 35.2 & & $334.01^{* *}$ \\
& & & \\
Transfer (n=21,179) & & 92.0 & \\
Transfer Status & 27.5 & 8.0 & \\
Freshman Status & 72.5 & & \\
\hline
\end{tabular}

$* \mathrm{p}<.01, * * \mathrm{p}<.001$.

\subsubsection{Choice of Major Field}

Significant differences between veteran and nonveteran students were also observed in students' choice of major field and the differences seem to explain of veteran effect in some extent. Our cross-tabulation results in Table 4 shows that student veterans were more likely than their nonveteran counterpart to choose academic majors that had negative effects on college GPA in the earlier regression analysis - i.e., engineering and applied sciences $(\beta=$ $-.11, \mathrm{p}<.001)$ and social sciences $(\beta=-.04, \mathrm{p}<.001)$. That is, $27.2 \%$ and $31.5 \%$ of veteran students reported engineering/applied sciences and social sciences, respectively, as their academic majors whereas only $16.1 \%$ and $17.3 \%$ of nonveteran students, respectively, did the same. Veteran students also seem to be less likely to choose arts and communication as their academic major while the major had positive effect on both college GPA $(\beta=.02, p<.01)$ and sense of belonging $(\beta=.02, p<.01)$ in the previous regression analysis. Less than $1.0 \%$ of veteran students in our sample chose arts and communication as their academic major, whereas $5.2 \%$ of nonveteran students did so. However, this result seems to need further investigation given that a substantial percentage of nonveteran students had not declared their major fields when the data were collected. 


\section{Macrothink}

Table 4. Students' Major Fields as a Percentage of Nonveteran and Veteran Student Sample

\begin{tabular}{llll}
\hline Major Field $(\mathrm{n}=21,176)$ & Nonveteran & Veteran & Chi-Square \\
\hline Arts and Communication & 5.2 & 0.6 \\
Business & 5.1 & 7.4 \\
Humanities & 6.7 & 12.3 \\
Engineering and Applied Science & 16.1 & 27.2 \\
Science or Math & 18.0 & 14.8 \\
Social Sciences & 17.3 & 31.5 \\
Undeclared & 31.6 & 6.2 \\
\hline
\end{tabular}

$* \mathrm{p}<.05, * * \mathrm{p}<.01, * * * \mathrm{p}<.001$.

\subsubsection{College Experiences}

Turning now to college experiences that were found earlier in the regression analyses to significantly predict college GPA and/or sense of belonging, the cross-tabulations results also showed some unique patterns for veteran students in those variables. Our regression results showed that extracurricular engagement had a positive effect on students' sense of belonging $(\beta=.07, \mathrm{p}<.001)$ and the cross-tabulation results in Table 5 suggest that veteran students seem to have lower level of extracurricular engagement compared to their civilian peers. That is, $12.5 \%$ of veteran students reported high level of extracurricular engagement, whereas $24.7 \%$ of nonveteran students did so. Work engagement during college was another significant experience that predicted both college GPA and sense of belonging, but the experience had a negative effect on the outcomes $(\beta=-.05, p<.001$ for GPA; $\beta=-.03$, $p$ $<.001$ for sense of belonging). Our cross-tab results showed that for this negative predictor, veteran students tend to report higher level of engagement than nonveteran students. In other words, $22.0 \%$ of veteran students in our sample reported high level of work engagement, whereas $19.6 \%$ of nonveteran students did so. 
Table 5. Students' College Experiences as a Percentage of Nonveteran and Veteran Student Sample

\begin{tabular}{|c|c|c|c|}
\hline College Experiences & Nonveteran & Veteran & Chi-Square \\
\hline \multicolumn{4}{|l|}{ High $^{a}$ Level of: } \\
\hline $\begin{array}{l}\text { Academic Participation and Interaction } \\
(\mathrm{n}=20,850)\end{array}$ & 23.8 & 41.6 & $31.709 * * *$ \\
\hline Collaborative Work $(\mathrm{n}=20,876)$ & 27.3 & 31.1 & $9.251 * * *$ \\
\hline $\begin{array}{l}\text { Extracurricular Engagement }(\mathrm{n}= \\
20,635)\end{array}$ & 24.7 & 12.5 & $37.157 * * *$ \\
\hline Time Employed $(n=20,772)$ & 19.6 & 22.0 & $10.290 * * *$ \\
\hline Academic Time $(\mathrm{n}=20,886)$ & 30.4 & 39.4 & $6.117 * * *$ \\
\hline
\end{tabular}

${ }^{a}$ High level roughly represents the upper quartile range of the full responses.

$$
* \mathrm{p}<.05, * * \mathrm{p}<.01, * * * \mathrm{p}<.001 .
$$

While patterns found from the cross-tabulations along with regression analyses generally explained some characteristics and conditions that contribute to negative effect of being a student veteran on college GPA and/or sense of belonging, there were also a few college experiences that need further investigation. For example, our regression results showed that academic participation and interaction had a positive effect on college GPA $(\beta=.09, \mathrm{p}<.001)$ and sense of belonging $(\beta=.11, \mathrm{p}<.001)$. For this positive predictor, our cross-tabulation results showed that student veterans tend to have a higher level of engagement than their nonveteran peers $(41.6 \%$ vs $23.8 \%)$. Collaborative work and academic time are other examples of mixed results of our regression analyses and cross-tabulations. Consequently, for these particular college experiences, our question is why student veterans tend to have lower level of college GPA and/or sense of belonging even though they have higher level of engagement in these experiences that have significant positive effects on the outcomes. Ideally, future research can examine the quality or perception of those experiences among veteran students or any conditional effects of the experiences depending on veteran status in order to explain the mixed findings.

\section{Limitations}

While this study attempts to contribute to the existing higher education literature by examining unique patterns of student characteristics, major choice, and college experiences among veteran student population in college, the study is limited in several aspects. First of all, small sample size of veteran students is perhaps the greatest limitation of the current study. The veteran population was severely underrepresented in the UCUES data $(0.8 \%$ of the final sample), which may limit the scope and nature of our findings when interpreted in some contexts. To address this issue, we note that while all of the null hypothesis significance tests (NHSTs) reported in this study indicated statistical significances of the findings, it should be noted, particularly when interpreting findings of cross-tabulations, that there may be some 
biases derived from the unequal sample size between veteran and nonveteran students.

The use of secondary data is another limitation of this study. While we assumed that other factors than college environments or experiences (e.g., service-related experiences, family commitment, Veteran Affairs benefit use, etc.) may possibly explain their unique patterns in college experiences or outcomes, these variables were not available in the UCUES data. Lastly, it is also important to acknowledge that the generalizability of findings of this study is limited in some sense. Given that the study used data from a single, highly selective research university system, the findings or implications of this study may not be equivalently applicable to other types of institutions.

\section{Discussion}

When we interpret the results of data analysis, we begin to understand the patterns of college experiences and outcomes for student veterans. In fact, we immediately see that student veterans report lower college GPAs and lower levels of sense of belonging on campus in spite of having higher levels of academic participation and interaction, academic time, and collaborative work compared to their counterparts who are not veterans. Further, we find that being a veteran student negatively and significantly affects one of these outcomes - college GPA - even after controlling for the levels of academic participation and interaction, academic time, collaborative work, extracurricular engagement, and time employed, along with a set of precollege characteristics and other college experiences.

What perplexes us is that despite reporting behavioral characteristics that we normally associate with college students who earn higher GPAs - interacting with faculty outside of class, community with faculty by email, working on a project with faculty outside of class, contributing to a class discussion, working with classmates on class projects, and spending more time studying - we do not find comparably higher GPAs among student veterans. On the whole, the GPAs that veterans in this sample report are not relatively low, but they are comparatively lower than students who engage in lower levels of activities that we associate with higher levels of academic achievement. That is, what we tend to identify with positive college outcomes are not related to a key achievement outcome-GPA — for student veterans even as they report with higher levels in these areas.

Overall, veteran status may not contribute practically to the model, but being a veteran is associated with a set of precollege characteristics and college experiences that are related to lower levels of achievement and sense of belonging. When we examine student veteran precollege characteristics and college experiences, we may partially explain for this finding. With respect to college GPA, we find that student veterans tend to report higher levels of work employment, lower levels of income, and lower levels of freshman status than their nonveteran counterparts. Indeed, despite spending more time studying, collaboratively working with peers, and interacting with faculty, that student veterans spend more time working and enter a research university as transfer students may intervene with the positive effects of stronger academic engagement. Consequently, in spite of having higher levels of investment in academic activities, student veteran investment may not be as meaningful as nonveteran students. 
Like college GPA, we find that student veterans report lower of sense of belonging in college. If we consider at their precollege characteristics and college experiences, we also find a way to partially explain this finding. In fact, as veteran students transfer to the university, enter as older students, work more, and engage in extracurricular activities less, we see a picture emerge of why student veterans do not feel like they belong on campus. Clearly, student veterans do not spend as much time being involved in campus activities that do not relate to academic studies or activities as nonveteran students.

While we find that explaining student veteran outcomes related to college GPA and sense of belonging in terms of their involvement in one type of campus activity or another is useful, we also note that the complex nature of veterans precollege characteristics and college experiences requires us to interpret these findings more comprehensively. In fact, we argue that student veteran investments in work and family may better explain their lower levels of investment in extracurricular activities and overall lower levels of college GPA and sense of belonging. Indeed, if challenged to balance family, work, and studies more frequently than nonveteran students, student veterans may not get as much out of their academic interactions with faculty, and peers inside and outside the classroom, which may possibly explain lower levels of GPA and sense of belonging.

Beyond balancing work and family commitments that compete with the demands of being a college student, veterans may interpret their college experiences through a military cultural lens. We know that veterans tend to retain their military cultural identities and values - some of which compete with cultural values that they encounter on college campuses. Within this context, student veterans who exhibit more frequent academic interaction and collaborative academic work may not interpret the cultural cues from the experiences. That is, the military cultural identities and values that student veterans tend to retain and investments in both family and work may explain less investment in some college experiences that strengthen academic and social integration associated with student success. As a result, even though student veterans do more to earn higher GPAs than students who are not veterans, they do not achieve academically or feel that they belong as much as students who are not veterans.

The findings from this study require us to further investigate why student behaviors that we tend to associate with positive college outcomes - academic participation and interaction and collaborative work, for example - are not related to a positive outcomes for veterans even though they exhibit higher levels in both categories. Indeed, the quality of interaction and participation between student veterans and faculty and peers appears to be a further area of inquiry. In addition, the nature of role negotiation and identity formation as students and members of the campus community seem to be a next step in understanding the college experiences and outcomes of student veterans. Regardless of the direction of future investigations, what we know from this study is that student veterans enter college with a distinct set of experiences and characteristics related to their military service, uniquely experience college academically and socially, and leave college with lower levels of GPA and sense of belonging. These findings are a first step in the direction of developing an understanding of who veterans in college are and how we can best support them as students. 


\section{References}

Allen, J., Robbins, S., Casillas, A., \& Oh, I. (2007). Third-year college retention and transfer: Effects of academic performance, motivation, and social connectedness. Research in Higher Education, 49(7), 647-664. http://dx.doi.org/10.1007/s11162-008-9098-3

Astin, A. W. (1984). Student involvement: A developmental theory for higher education. Journal of College Student Personnel, 25, 297-308.

Astin, A. W. (1993). What matters in college: Four critical years revisited. San Francisco: Jossey-Bass.

Banks, J. A. (1993). The cannon debate: Knowledge construction and multicultural education. Educational Researcher, 22, 4-14.

Bollen, K. A., \& Holye, R. (1990). Perceived cohesion: A conceptual and empirical examination. Social Forces, 69(2), 479-504.

Chatman, S. (2007a). Overview of University of California Undergraduate Experience Survey (UCUES) response rates and bias issues. Center for Studies in Higher Education. Berkeley, CA.

Chatman, S. (2007b). Institutional versus academic discipline measures of student experience: A matter of relative validity. Center for Studies in Higher Education. Berkeley, CA.

Hall, C., Smith, K., \& Chia, R. (2008). Cognitive and personality factors in relation to timely completion of a college degree. College Student Journal, 42(4), 1087-1098.

Hausmann, L. R.M., Schofield, J. W., \& Woods, R. L. (2007). Sense of belonging as a predictor of intentions to persist among African American and White first-year college students. Research in Higher Education, 48(7), 803-839. http://dx.doi.org/10.1007/s11162-007-9052-9

Hoffman, M., Richmond J., Morrow, J., \& Salomone, K. (2002). Investigating "Sense of Belonging" in first-year college students. Journal of College Student Retention, 4(3), 227-256. http://dx.doi.org/10.2190/DRYC-CXQ9-JQ8V-HT4V

Hurtado, S., Han, J., Sáenz, V., Espinosa, L., Cabrera, N., \& Cerna, O. (2007). Predicting transition and adjustment to college: Biomedical and behavioral science aspirants' and minority students' first year of college. Research in Higher Education, 48(7), 841-887. http://dx.doi.org/10.1007/s11162-007-9051-x

Kelly, W. E. (2004). As achievement sails the river of time: The role of time use efficiency in grade-point-average. Educational Research Quarterly, 27(4), 3-8.

Kern, C. W., Fagley, N. S., \& Miller, P. M. (1998). Correlates of college retention and GPA: Learning and study strategies, testwiseness, attitudes, and ACT. Journal of College Counseling, 1(1), 26. http://dx.doi.org/10.1002/j.2161-1882.1998.tb00121.x

Kim, Y., \& Sax, L. (2009). Student-faculty interaction in research universities: Differences 
by student gender, race, social class, and first-generation status. Research in Higher Education, 50(5), 437-459. http://dx.doi.org/10.1007/s11162-009-9127-x

Livingston, W. (2009). Discovering the academic and social transitions of re-enrolling student veterans at one institution: A grounded theory. Ph.D. 3355150, Clemson University, United States -- $\quad$ South Carolina. Retrieved from http://libproxy.csun.edu/login?url=http://proquest.umi.com/pqdweb?did=1751640951\&Fmt= 7\&clientId=17859\&RQT=309\&VName=PQD

Lucas, T., \& Robinson, J. (2003). Reaching them early: Identifying and supporting prospective teachers. Journal of Education for Teaching, 29(2), 159. http://dx.doi.org/10.1080/0260747032000098444

Ly-Turnbull, T. (2010). Unconventional classmates: Veterans' transitions from war to college. M.S. 1486115, Southern Connecticut State University, United States -- Connecticut. Retrieved from http://libproxy.csun.edu/login?url=http://proquest.umi.com/pqdweb?did=2140466091\&Fmt= $7 \&$ clientId $=17859 \&$ RQT $=309 \& \mathrm{VName}=\mathrm{PQD}$

McNealy, T. E. (2004). Veterans' college choices: A process of stratification and social reproduction. Ph.D. 3145098, The University of Arizona, United States -- Arizona. Retrieved from http://libproxy.csun.edu/login?url=http://proquest.umi.com/pqdweb?did=795925091\&Fmt=7 \&clientId $=17859 \&$ RQT $=309 \&$ VName $=$ PQD

Moody, V.R. (2004, January-February). Sociocultural orientations and the mathematical success of African American students. The Journal of Educational Research, 97(3), 135-146. http://dx.doi.org/10.3200/JOER.97.3.135-146

Nguyen, N. T., Allen, L. C., \& Fraccastoro, K. (2005). Personality predicts academic performance: Exploring the moderating role of gender. Journal of Higher Education Policy \& Management, 27(1), 105-116. http://dx.doi.org/10.1080/13600800500046313

Noftle, E. E., \& Robins, R. W. (2007). Personality predictors of academic outcomes: Big five correlates of GPA and SAT Scores. Journal of Personality \& Social Psychology, 93(1), 116-130. http://dx.doi.org/10.1037/0022-3514.93.1.116

Pascarella, E. T., \& Terenzini, P. T. (2005). How college affects students. (Vol. 2): A third decade of research. Jossey-Bass, San Francisco, CA: San Francisco Jossey-Bass.

Radford, A.W. (2009). Military service members and veterans in higher education: What the new GI Bill may mean for postsecondary institutions. Washington, DC: American Council on Education.

Radford, A.W., \& Wun, J. (2009). Issue tables: A profile of military service members and veterans in higher education. Washington, DC: U.S. Department of Education, National Center for Education Statistics. Retrieved from http://nces.ed.gov/pubsearch/pubsinfo.asp?pubid=2009182. 
Richardson, M., \& Abraham, C. (2009). Conscientiousness and achievement motivation predict performance. European Journal of Personality, 23(7), 589-605. http://dx.doi.org/10.1002/per.732

Rumann, C.R. (2010). Student veterans returning to a community college: Understanding their transitions. Ph.D. 3403830, Iowa State University, United States -- Iowa. Retrieved from

http://libproxy.csun.edu/login?url=http://proquest.umi.com/pqdweb?did=2057883181\&Fmt= 7\&clientId $=17859 \&$ RQT $=309 \&$ VName $=$ PQD

Rumann, C.R., \& Hamrick, F.A. (2010, July/August). Student soldiers in transition: Re-enrolling after war zone deployments. The Journal of Higher Education, 81(4), 431-458. http://dx.doi.org/10.1353/jhe.0.0103

Teachman, J. (2005, January). Military service in the Vietnam Era and educational attainment. Sociology of Education, 78, 50-68. http://dx.doi.org/10.1177/003804070507800103

Teachman, J. (2004, December). Military service during the Vietnam Era: Were there consequences for subsequent civilian earnings? Social Forces, (83)2, 709-730. http://dx.doi.org/10.1353/sof.2005.0021

Zajacova, A., Lynch, S. M., \& Espenshade, T. J. (2005). Self-efficacy, stress, and academic success in college. Research in Higher Education, 46(6), 677-706. http://dx.doi.org/10.1007/s11162-004-4139-z

\section{Appendix}

Appendix 1. Variable Definition and Coding Scheme

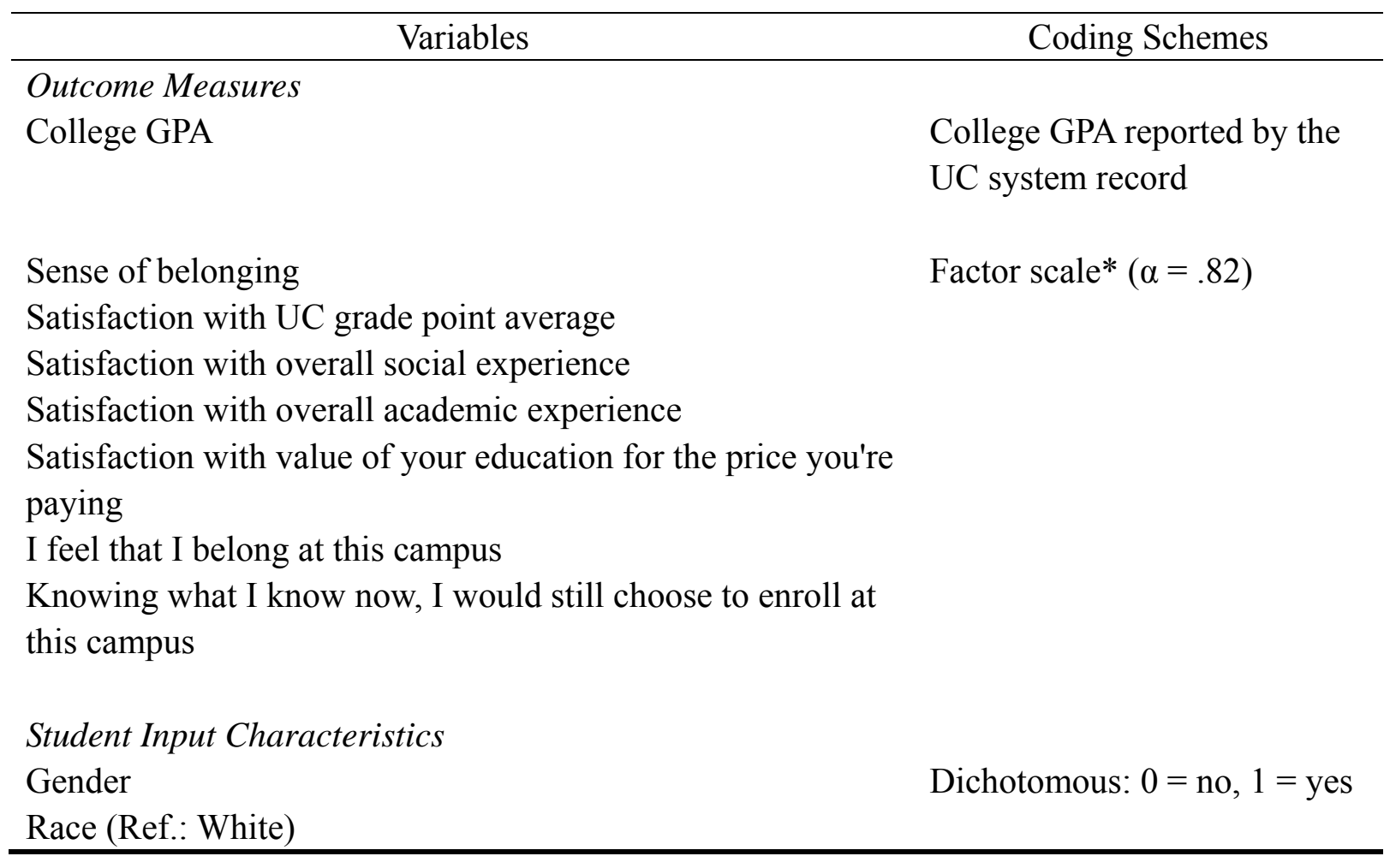




\section{Macrothink Institute ${ }^{\mathrm{TM}}$}

African American

Asian American

Latino

Age

Total parental annual income

Freshman status

Veteran status

Major Fields (Ref.: Undeclared)

Engineering or Applied Science

Science or Math

Social Science

Arts and Communications

Business

Humanities

\section{College Experiences}

Academic Participation and Interaction

Taken a small research-oriented seminar with faculty

Communicated with a faculty member by email or in person

Talked with the instructor outside of class about issues and concepts derived from a course

Interacted with faculty during lecture class sessions

Worked with a faculty member on an activity other than coursework (e.g., student organization, campus committee, cultural activity)

Contributed to a class discussion

Brought up ideas or concepts from different courses during class discussions

Asked an insightful question in class

Found a course so interesting that you did more work than was required

Chosen challenging courses, when possible, even though you might lower your GPA by doing so

Made a class presentation

Had a class in which the professor knew or learned your name
Journal of Studies in Education

ISSN 2162-6952 2012, Vol. 2, No. 2

All dichotomous: $0=$ no, $1=$ yes

Range from 16 to 73

Eleven-point scale: $1=$ less

than 10,000 , to $11=200,000$

or more

Dichotomous: $0=$ no, $1=$ yes

Dichotomous: $0=$ no, $1=$ yes

All dichotomous: $0=$ no, $1=$ yes

Factor Scale* $(\alpha=.90)$ 


\section{Macrothink Institute ${ }^{\text {TM }}$}

Collaborative Work

Sought academic help from instructor or tutor when needed Worked on class projects or studied as a group with other classmates outside of class

Helped a classmate better understand the course material when studying together

Campus Climate for Diversity

I feel free to express my political beliefs on campus

I feel free to express my religious beliefs on campus

Students are respected here regardless of their economic or social class

Students are respected here regardless of their gender

Students are respected here regardless of their race or ethnicity

Students are respected here regardless of their religious beliefs

Students are respected here regardless of their political beliefs

Students are respected here regardless of their sexual orientation

Extracurricular Engagement

Attending movies, concerts, sports, or other entertainment events

Participating in physical exercise, recreational sports, or physically active hobbies

Participating in student clubs or organizations

Pursuing a recreational or creative interest (arts/crafts, reading, music, hobbies, etc.)

Socializing with friends

Partying

Using the computer for non-academic purposes (games, shopping, email/instant messaging, etc.)

Watching TV

Time Employed

Paid employment (include paid internships)

Of your total hours spent working for pay, about how many hours did you work on campus?

Of your total hours spent working for pay, about how many hours were related to your academic interests?
Journal of Studies in Education

ISSN 2162-6952 2012, Vol. 2, No. 2

Factor Scale* $(\alpha=.70)$

Factor Scale* $(\alpha=.90)$

Factor Scale* $(\alpha=.72)$

Factor Scale* $(\alpha=.67)$ 
Academic Time

Factor Scale* $(\alpha=.54)$

Attending classes, discussion sections or labs

Studying and other academic activities outside of class

*Factor scales developed by Center for Studies in Higher Education, UC Berkeley.

\section{Copyright Disclaimer}

Copyright reserved by the author(s).

This article is an open-access article distributed under the terms and conditions of the Creative Commons Attribution license (http://creativecommons.org/licenses/by/3.0/). 